\title{
NFKB2 Gene Product
}

National Cancer Institute

\section{Source}

National Cancer Institute. NFKB2 Gene Product. NCI Thesaurus. Code C129922.

A protein encoded by the NFKB2 gene. 